\title{
Restoring good manners in research
}

The need for good manners arises from a conflict in the foundations of the research enterprise. Journals have much to do to put things right, but the chief responsibility rests with academic institutions.*

Is there an intrinsic conflict in the principles on which the scientific enterprise is based? Everybody agrees that science is a cumulative enterprise in which people stand on others' shoulders "to see further"; Copernicus and Galileo were among "the giants" on whose shoulders Newton stood, but there were Galileo's lens grinders and polishers whom he did not mention. Now, the cumulative character of the enterprise means that spectacular discoveries (say the structure of DNA) are rare, but that lesser discoveries are necessarily precursors and are therefore equally estimable. Good science is good science, whatever its importance, and its practitioners are equally deserving of respect. International interdependence flows from that.

Second, publication is of the essence. A discovery has no meaning unless an account of it is generally available. Paradoxically, equipment is more vulnerable to the passage of time than an account in words of the use made of it. But the function of publication is more than the transmission of the news to others. It is the only means by which the record of discovery can be authenticated in the long run; critical readers pick holes in the logic, others test for consistency by telling whether some field can be welded into a coherent whole. (One of the problems yet to be solved in electronic publications is that of telling which is the authentic text.)

Third, the traditional and, until recently, the sole reward of the working scientist has been his or her bibliography. It is a curiously insubstantial proof that a lifetime's science has been well done, but when the deepening of understanding is a cumulative business, even a handful of good papers rightly engender pride. The other traditional component of the profession's reward structure is the joy of teaching students successfully. It is impressive how often senior people list the names of erstwhile graduate students who are themselves now senior and productive people. The solicitude of the profession for its students is its most appealing attribute.

Where, in this account of an altruistic research profession, can there be conflict? If publication is essential to the authentication of discovery and also relevant to a researcher's self-esteem (and to the esteem accorded him or her by others), how can (and how strongly should) the temptation to improve the lustre of a personal bibliography be resisted? Succumbing to temptation distorts, even corrupts, the record.
That is why there had emerged in the old days (and people will differ over how long ago they were) a code of conduct, an etiquette, to which people adhered more or less scrupulously.

Good manners were simple. A person should write and talk openly about past accomplishments and even future plans, answering intelligent questions even from competitors. Research data and materials should be shared with serious people, at least after the relevant papers had been published. Peripheral contributions to a piece of work should be generously acknowledged for what they are, and not dignified by co-authorship. Although Sir William Ramsay's plea a century ago that people should not follow up a discovery without the permission of the discoverer asks too much of science as well as its practitioners, to fail to give full credit to pathfinders in a field is not merely discourteous, but a way of robbing them of their own place in the record of discovery. And people established in a field have a professional duty to comment on the work of others in the capacity of referees.

Fifty years ago, these principles were widely followed, even in busy and productive university departments. The principles are still understood and still widely followed. Journals are especially conscious of what this entails. Nature's demands on its referees are clamant and onerous; it is a constant source of wonder that so many offer such careful, judicious and constructive reports on manuscripts people working in fields related to their own interests are anxious to have published. Good manners still obtain.

But there is evidence in the hands of all journals that bad manners increasingly coexist with good. Self-advertisement is more common now than it used to be. People refer to their own publications when others' would be more apt. When reference to competitors is unavoidable, they may refer to a minor paper, ignoring a more important work. (But not so long ago, a Japanese author who will recall the circumstances referred to an inappropriate publication by a prominent US scientist in the belief that such modesty would help ensure publication.) The tendency to overlook publications in other languages, or even by colleagues in other countries, is a growing source of angst. So to is the use of the word "first", as in "We have for the first time shown that Ohm's Law is valid in spacecraft beyond Jupiter (or Neptune, or
Pluto, as the case may be).

The perils of honorary co-authorship are now well documented, not least by Feder and Stewart's investigation of the circumstances in which John C. Darsee, at Emory University and the Harvard Medical School, was routinely able to recruit distinguished people as fellow-authors. The difficulty is that people with responsibility for administration and fund-raising are supposed to be more effective at those tasks if they can also boast of a research record.

There are also lapses from good manners by the gallant company of referees. As long ago as 1967, a paper on the metallurgy of austentitic steel was returned from a referee with the opinion that it did not deserve publication; the referee enclosed a paper of his own saying much the same thing, not manifestly more compellingly. Cases in which the sight of an authors paper has stimulated referees to publish their own parallel work elsewhere have been recorded. The assumption that referees always treat a manuscript as confidential seems not always to be valid.

What can be done to bring back good manners? Journals have a responsibility to be more severe on offending manuscripts, and to make public flagrant trangressions of the unwritten rules. They have a particular duty to fight against that form of obscurity that stems not from a poor grasp of language, but from a wish to shelter from clarity in case is should be more vulnerable to criticism. It may make sense to ask corresponding authors to vouch for the collective responsibility of all co-authors.

But academic institutions and grantmaking agencies have the chief responsibility. The temptation to magnify an individual bibliography, always present and usually resisted, is magnified by the pressure to win promotion and research funds, where decisions may hang on bibliometric indices of some kind. Because the importance of a discovery may seem, at least in its authors' minds, to be magnified by reports in the general press and thus by being first, anxiety over priority mounts.

Yet little thought has been given to mechanisms for decreasing the pressure to publish and to be first - especially in the United States where they are strongest, and which sets the tone for the rest of science. Until that is done, good manners will remain under threat.

John Maddox

* Gist of an address to the International Federation of Science Editors, Barcelona, 9 July. 